\title{
Differentiation of Xanthomonas translucens f.sp. oryzicola (Fang et al.) Bradbury, the Leaf-Streak Pathogen, from Xanthomonas oryzae (Uyeda and Ishiyama) Dowson, the Blight Pathogen of Rice, by Enzymatic Tests
}

\author{
O. R. REDDY and S. H. OU \\ The International Rice Research Institute, Los Baños, Philippines
}

\begin{abstract}
Isolates of Xanthomonas translucens f.sp. oryzicola readily produced phenylalanine deaminase 1 day after inoculation and tyrosinase and $\beta$-glucosidase 4 days after inoculation, but isolates of Xanthomonas oryzae showed no such enzymatic activities by the methods employed. These differences easily distinguish bacterial blight of rice (caused by $X$. oryzae) from leaf streak of rice (caused by $X$. translucens f.sp. oryzicola).
\end{abstract}

In the tropics the two most common bacterial diseases of the rice plant are blight and leaf streak. Bacterial blight, known for many years, is caused by Xanthomonas oryzae (Uyeda and Ishiyama) Dowson (3). Fang et al. (5) distinguished leaf streak from blight and named the leaf-streak pathogen Xanthomonas oryzicola. Since then conflicting reports on the naming of the leaf-streak organism $(1,6,12)$ began to appear. Pordesimo (12), working with a bacterial disease of rice in the Philippines, which he thought was bacterial blight, proposed that $X$. oryzae be revised to $X$. translucens (Jones, Johnson, and Reddy) Dowson f.sp. oryzae. His illustrations showed, however, that the disease he studied was not blight but leaf streak. Goto (6) suggested a close relationship between $X$. oryzicola and $X$. translucens. After carefully studying their symptoms and bacteriological properties, he identified $X$. translucens f.sp. oryzae Pordesimo as the leaf-streak organism. Bradbury (1) proposed renaming the leaf-streak pathogen $X$. translucens (Jones, Johnson, and Reddy) Dowson f.sp. oryzicola Fang et al., since the earlier nomenclature caused confusion between the two organisms. All the authors mentioned failed to differentiate the pathogens from one another by physiological characteristics. This paper reports a study aimed at determining whether specific enzymatic tests can readily distinguish one pathogen from the other.

\section{MATERIALS AND METHODS}

Bacterial cultures. Forty isolates of $X$. oryzae and 16 isolates of $X$. translucens f.sp. oryzicola were selected from the bacterial stock cultures of the Plant Pathology Department of the International Rice Research Institute, Manila. The cultures were maintained on Wakimoto (18) agar slants (potato, $300 \mathrm{~g}$; $\left.\mathrm{Ca}\left(\mathrm{NO}_{3}\right)_{2}\right) \cdot 4 \mathrm{H}_{2} \mathrm{O}, 0.5 \mathrm{~g} ; \mathrm{Na}_{2} \mathrm{HPO}_{4} \cdot 12 \mathrm{H}_{2} \mathrm{O}, 2.0 \mathrm{~g}$; peptone, $5.0 \mathrm{~g}$; sucrose, $15.0 \mathrm{~g}$; agar, $20.0 \mathrm{~g}$; distilled water, $1,000 \mathrm{ml}$; $\mathrm{pH}$ adjusted to 6.8 to 7.0 ) in a deep freezer at $-30 \mathrm{C}$. Twenty-four-hour-old agar slant cultures were used in inoculating test media, and they were incubated at $\pm 28 \mathrm{C}$ after inoculation.

Biochemical tests. Arginine hydrolase was ascertained by the method of Thornley (17), and asparagine hydrolase was tested similarly with $1 \%$ L-asparagine, whereas arginine decarboxylase and phenylalanine deaminase were determined by using the procedures described by Skerman (14). Catalase was detected with 10 vol of $\mathrm{H}_{2} \mathrm{O}_{2}$, and oxidase was tested with $1 \% \quad N, N$-dimethyl-p-phenylenediammonium dichloride (Merck) according to Kovacs (9) and Ewing and Johnson (4). Similarly, tyrosinase was demonstrated with L-tyrosine (19) and $\beta$-glucosidase with $0.5 \%$ arbutin (8) after 4 days of incubation. Esculin hydrolysis was observed by the method of Sneath (15). Lipase was detected by the method of Sierra (13), and urease was tested in Christensen urea-agar medium (2).

\section{RESULTS AND DISCUSSION}

Table 1 shows that all the isolates of $X$. translucens f.sp. oryzicola, the leaf-streak pathogen, and of $X$. oryzae, the blight bacterium, produced catalase and lipase, and hydrolyzed esculin, but they reacted negatively to tests for arginine hydrolase and decarboxylase, asparagine hydrolase, cytochrome oxidase, and urease. The leaf-streak cultures differed distinctly from those of blight in their ability to produce $\beta$-glucosidase, tyrosinase, and phenyl- 
TABLE 1. Some characteristics of the leaf-streak pathogen and the blight bacterium

\begin{tabular}{l|c|c}
\hline \multirow{2}{*}{ Test } & \multicolumn{2}{|c}{ Organism } \\
\cline { 2 - 3 } & $\begin{array}{c}\text { X. translucens } \\
\text { f.sp. oryzicola } \\
\text { (leaf streak) }\end{array}$ & $\begin{array}{c}\text { X. oryzae } \\
\text { (bacterial } \\
\text { blight) }\end{array}$ \\
\hline Esculin hydrolysis & $+^{a}$ & + \\
Catalase & + & + \\
Lipase & + & + \\
$\beta$-Glucosidase & + & - \\
Phenylalanine deaminase & + & - \\
Tyrosinase & - & - \\
Arginine decarboxylase & - & - \\
Arginine hydrolase & - & - \\
Asparagine hydrolase & - & - \\
Cytochrome oxidase & - & - \\
Urease & - & - \\
\hline
\end{tabular}

$a+$, Positive; - , negative.

alanine deaminase. Recently, Sridhar et al. (16) reported that lipid globules are readily discolored in response to leaf-streak infection. Also, it is evident that phenols are localized in the butiliform cells and in the lipid bodies. Neish (11) showed that a wide variety of aromatic compounds which play a key role in the phenol metabolism of hosts are formed from phenylalanine deaminase and tyrosinase, respectively. Hildebrand and Schroth (7) reported that the hydrolysis of glucoside arbutin by $\beta$-glucosidase yielded a variety of quinones. The reddening of the lipid droplets in rice leaf tissues during the early stages of leaf-streak development, the browning of the lesion, and the restriction of its development suggest that the three enzymes play a role in forming a complex of melanoid pigments caused by polymerization of quinones. The present results are in accordance with those of Murata and Starr (10), who reported that $X$. oryzae and $X$. translucens f.sp. oryzicola related only at the $10 \%$ level, whereas complete deoxyribonucleic acid homology is found between $X$. translucens and $X$. translucens f.sp. oryzicola. They also reported that the guanine plus cytosine content of $X$. translucens and $X$. translucens f.sp. oryzicola is highest with a value of $69.0 \%$, in comparison with a value of $64.4 \%$ for $X$. oryzae. Thus, it is evident that $X$. translucens f.sp. oryzicola, the leaf-streak pathogen, is distinctly different from $X$. oryzae, and it is genetically related to $X$. translucens.

\section{REPRINT REQUESTS}

Address 'reprint requests to: Dr. S. H. Ou, The International Rice Research Institute, P. O. Box 933, Manila, Philippines.

\section{LITERATURE CITED}

1. Bradbury, J. F. 1971. Nomenclature of the bacterial leaf streak pathogen of rice. Int. J. Syst. Bacteriol. 21:72.

2. Christensen, W. B. 1946. Urea decomposition as a means of differentiating Proteus and paracolon organisms from each other and from Salmonella and Shigella types. J. Bacteriol. 52:461.

3. Dowson, W. J. 1943. On the generic names Pseudomonas, Xanthomonas and Bacterium for certain bacterial plant pathogens. Trans. Brit. Mycol. Soc. 26:1-14.

4. Ewing, W. H., and J. G. Johnson. 1960. The differentiation of Aeromonas and $\mathrm{C} 27$ cultures from Enterobacteriaceae. Int. Bull. Bacteriol. Nomencl. Taxon. 10:223.

5. Fang, C. T., H. C. Ren, T. Y. Chen, Y. K. Chu, H. C. Faan, and S. C. Wu. 1957. A comparison of the rice bacterial leaf blight organism with the bacterial leaf streak organism of rice and Leersia hexandra Swartz. (In Chinese with English summary) Acta Phytopathol. Sinica 3:99-124.

6. Goto, M. 1964. Nomenclature of the bacteria causing bacterial leaf streak and bacterial stripe of rice. Bull. Fac. Agr. Shizuoka Univ. 14:3-10.

7. Hildebrand, D. C., and M. N. Schroth. 1963. Relation of arbutin-hydroquinone in pear blossoms to invasion by Erwina amylovora. Nature (London) 197:153.

8. Hildebrand, D. C., and M. N. Schroth. 1964. $\beta$-Glucosidase activity in phytopathogenic bacteria. Appl. Microbiol. 12:487-491.

9. Kovacs, N. 1956. Identification of Pseudomonas pyocyanea by the oxidase reaction. Nature (London) 178:703.

10. Murata, N., and M. P. Starr. 1973. A concept of the genus Xanthomonas and its species in the light of segmental homology of deoxyribonuclei acids. Phytopathol. Z. 77:285-323.

11. Neish, A. C. 1960 . Biosynthetic pathways of aromatic compounds. Annu. Rev. Plant Physiol. 11:55-80.

12. Pordesimo, A. N. 1958. Bacterial blight of rice. Philipp. Agr. 42:115-118.

13. Sierra, G. 1956. A simple method for the detection of lipolytic activity of microorganisms and some observations on the influence of the contact between cells and fatty substrates. Antonie van Leeuwenhoek J. Microbiol. Serol. 23:15-22.

14. Skerman, V. B. D. 1967. A guide to the 
identification of the genera of bacteria, 2 nd ed. The Williams and Wilkins Co., Baltimore.

15. Sneath, P. H. A. 1960 . A study of the bacterial genus Chromobacterium. Iowa State J. Sci. 34:243.

16. Sridhar, R., I. W. Buddenhagen, and S. H. Ou. 1973. Presence of lipid bodies in rice leaves and their discoloration during pathogenesis. Experientia 29:959.

17. Thornley, M. J. 1960. The differentiation of
Pseudomonas from other gram-negative bacteria on the basis of arginine metabolism. J. Appl. Bacteriol. 23:37-52.

18. Wakimoto, S. 1967. Strains of Xanthomonas oryzae in Asia and their virulence against rice varieties, p. 11-18. In Proc. Symp. on Rice Diseases and Their Control by Growing Resistant Varieties and Other Measures, Tokyo.

19. Waksman, S. A. 1967. The actinomycetes. Ronald Press Co., New York. 